\title{
PENERAPAN DATABASE DALAM BORLAND DELPHI
}

\author{
Adenisa Refitasari \\ 165100034
}

Fakultas Komputer, 448757162

Adenisarefitasari.student@umitra.ac.id

\begin{abstract}
Program database siswa dibuat dengan bahasa Pemprograman Borland Delphi dengan menggunkan database Access, merupakan contoh Aplikasi yang sederhana, dimana akan ada sebuah Form yang menampilkan Biodata siswa beserta fotonya dan satu buah form lagi yang berguna untuk input data siswa yang baru. Program ini salah satunya menggunakan komponen Open Picture Dialog sebagai komponen yang dapat memanggil File Foto .JPG. bagaimana cara pemanggilan file-file tersebut, yaitu dengan perintah Image, Picture, Load From File (Open Picture Dialog 1,Filename) pada Bahasa Pemprograman Borland Delphi.
\end{abstract}

Kata Kunci : Menampilkan Biodata Siswa beserta foto.

\section{A. INTRODUCTION}

Membuat Sebuah Database Access Siswa Beserta Foto Menggunakan Delphi?

\section{Jawaban :}

1. Buatlah 1 folder baru dengan nama siswa

2. Di dalam Folder siswa buat 3 buah sub folder :

- Applikasi

- Database

- Foto

3. Buat Database di acccess dengan nama siswa dan tbsiswa untuk nama tabelnya

4. Buat New Project di dephi

5. Simpanlah semua foto siswa .JPG di folder foto yang telah disediakan

6. Boleh di Run

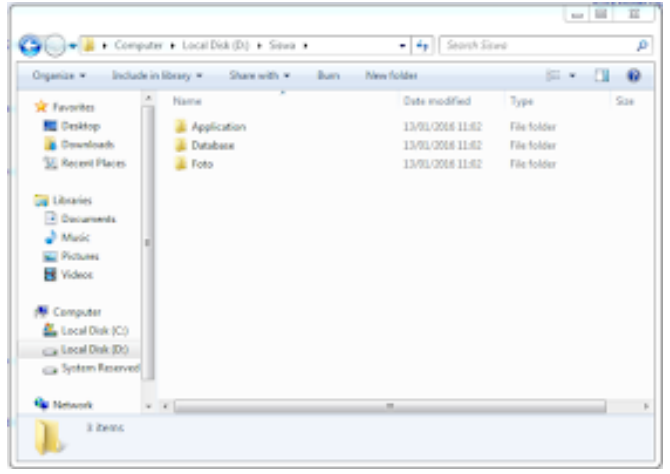

\section{Buat Database Access}

Pastikan type field foto adalah text! Contoh isi Field foto D: Isiswalfotoladenisa.jpg 


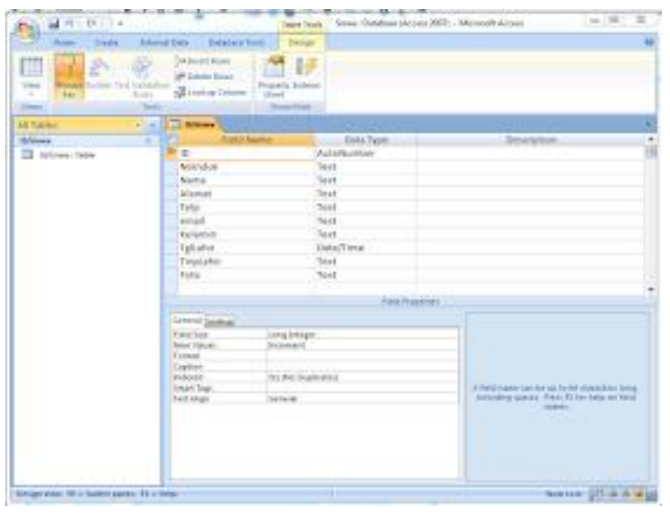

8. Buat New Project

Disini kita akan membuat form Siswa ya guys..

- Membuat Form Siswa

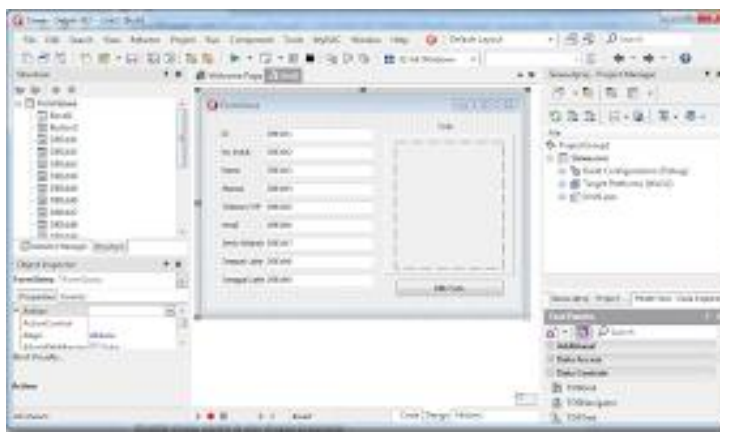

- Menghubungkan Program

Aplikasi dengan database Access
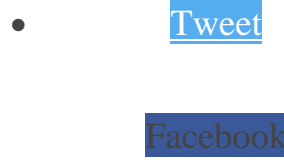

-
Dengan ada nya bahasa pemograman Delphi ini sangat menarik bagi para programer, Secara bahasa pemograman Delphi termasuk dalam tingkat tinggi sehingga relatif lebih mudah dipahami untuk membantu pekerjaan kita.

C. ACKNOWLEDGEMENT University Of Indonesia University Of Mitra Indonesia Telkom University University Of Mellbourne Saitama University

\section{REFERENCE(Based ISO 690 )}

\section{B. CONCLUSION}

Kesimpulan dari materi ini adalah ...
A. S. Putra And O. M. Febriani, "Knowledge Management Online Application In Pdam 
Lampung Province," In Prosiding International Conference On Information Technology And Business (Icitb), 2018, Pp. 181-187.

[2] A. S. Putra, O. M. Febriani, And B. Bachry, "Implementasi Genetic Fuzzy System Untuk Mengidentifikasi Hasil Curian Kendaraan Bermotor Di Polda Lampung," J. Sist. Inf. Dan Manaj. Basis Data, Vol. 1, No. 1, Pp. 21-30, 2018.

[3] O. M. Febriani And A. S. Putra, "Sistem Informasi Monitoring Inventori Barang Pada Balai Riset Standardisasi Industri Bandar Lampung," J. Inform., Vol. 13, No. 1, Pp. 90-98, 2014.

[4] Putra, Arie Setya. "2018 Artikel Struktur Data, Audit Dan Jaringan Komputer." (2018).

[5] Putra, A. S. (2018, July 17). Paperplain Fundamental Create Application With Borland Delphi 7.0 University Of Mitra Indonesia. Retrieved From Osf.Io/Pbrn9.

\section{E. REFERENCE(Based APA )}

Putra, A. S., Aryanti, D. R., \& Hartati, I. (2018, November). Metode SAW (Simple Additive Weighting) sebagai Sistem Pendukung Keputusan Guru Berprestasi (Studi Kasus: SMK Global
Surya). In Prosiding Seminar Nasional Darmajaya (Vol. 1, No. 1, pp. 85-97).

Sari, D. P., Febriani, O. M., \& Putra, A. S. (2018, November). Perancangan Sistem Informasi SDM Berprestasi pada SD Global Surya. In Prosiding Seminar Nasional Darmajaya (Vol. 1, No. 1, pp. 289-294).

Putra, A. S. (2018). Paperplain: Execution Fundamental Create Application With Borland Delphi 7.0 University Of Mitra Indonesia.

Putra, A. S., Sukri, H., \& Zuhri, K. Sistem Monitoring Realtime Jaringan Irigasi Desa (JIDES) Dengan Konsep Jaringan Sensor Nirkabel. IJEIS (Indonesian Journal of Electronics and Instrumentation Systems), 8(2), 221232.

Darmawan, A., Yuliawati, D., Marcella, O., \& Firmandala, R. (2016). Sistem Absensi dan Pelaporan Berbasis Fingerprint dan SMS Gateway. EXPLORE, 7(1).

Febriani, O. M., Wahyuni, T., \& Yusuf, S. (2017). DESIGN OF WEBSITE-BASED INFORMATION SYSTEM FOR EDOCUMENT ADMINISTRASI IN THE COMMUNITY SERVICE UNIT (A Case Study at Rajabasa District). INTERNATIONAL JOURNAL OF COMPUTERS \& TECHNOLOGY, 16(7), 7010-7020.

Febriani, O. M., \& Wahyuni, T. (2017, October). PERANCANGAN SISTEM E-DOCUMENT ADMINISTRASI LOGBOOK PENELITIAN PADA 
UNIT LAYANAN DI BANDAR LAMPUNG. In Prosiding Seminar Nasional Darmajaya (Vol. 1, No. 1, pp. 187-194).

Febriani, O. M., \& Permadi, A. B. (2017). Implementasi Sistem Aplikasi Data Bimbingan dan Pelanggaran Siswa pada Sekolah Menengah Atas di Lampung Tengah dengan Metode Analisis dan Desain Sistem Terdistribusi (SSAD). EXPERT, 7(1).

Febriani, O. M., \& Ambarwati, L. (2015). PERANCANGAN APLIKASI PENGOLAHAN DATA PENJUALAN UKM KELANTING KHAS TELO DESA SIDOHARJO KECAMATAN JATI AGUNG KABUPATEN LAMPUNG SELATAN. Jurnal Teknologi Informasi dan Bisnis Pengabdian Masyarakat Darmajaya, 1(1), 77-95.

Febriani, O. M. (2015). Rancang Bangun Aplikasi Ecommercemenggunakan Freewebstore pada UKM Kelanting di Desa Sidoharjo Lampung Selatan. Prosiding Sembistek 2014, 1(02), 446-458. 